\title{
Analisis Daya Dukung Pondasi Tiang Pancang Dengan Metode Formula Dinamis Pada Jembatan Nasional Alue Lamteh - Aceh
}

\author{
Fauzan Mufid ${ }^{1}$ Munirwansyah ${ }^{2}$ Halida Yunita $^{3}$ \\ 1,2,3 Universitas Syiah Kuala \\ Email: Fauzan1099@mhs.unsyiah.ac.id
}

\begin{abstract}
The bridge is a construction consisting of an upper structure and a lower structure that serves to connect two roads that are cut off due to lower obstacles such as rivers and others. The object of this research is the Alue Lamteh Bridge Widening Project. The Alue Lamteh Bridge is a bridge located in Keumireu Village, Kuta Cot Glie, Aceh Besar District at coordinates $5^{\circ} 23^{\prime} 42.4^{\prime \prime} N$ and $95^{\circ} 29^{\prime} 35.9^{\prime \prime}$ E. The purpose of this study was to analyze the dynamic bearing capacity of the pile foundation on the Alue Lamteh Bridge Widening Project. The dynamic bearing capacity of the pile was calculated using the Janbu, ENR-Modified, CNB, PCUBC and Hiley methods. Based on the calculation of the dynamic bearing capacity, the largest bearing capacity was obtained using the ENR-Modified method on the P1.2 and P3.2 piles with $s=12$ mm each of 83,488 tons while the smallest bearing capacity was using the PCUBC method on the P2.2 pile. with $\mathrm{s}=24 \mathrm{~mm}$ of 35,470 tons.
\end{abstract}

Keywords: pile foundation, dynamic formula, calendering test, bearing capacity

\begin{abstract}
Abstrak
Jembatan merupakan sebuah konstruksi yang terdiri dari struktur atas dan struktur bawah yang berfungsi untuk menghubungkan dua ruas jalan yang terputus akibat adanya rintangan yang lebih rendah seperti sungai dan lainnya. Objek yang menjadi tinjauan penelitian ini adalah Proyek Pelebaran Jembatan Alue Lamteh. Jembatan Alue Lamteh merupakan jembatan yang berlokasi di Desa Keumireu, Kecamatan Kuta Cot Glie, Kabupaten Aceh Besar pada titik koordinat 5'23 '42,4 " LU dan 95'29'35,9” BT. Tujuan penelitian ini adalah untuk menganalisis daya dukung dinamis pondasi tiang pancang pada Proyek Pelebaran Jembatan Alue Lamteh. Daya dukung dinamis tiang pancang dihitung menggunakan metode Janbu, ENR-Modified, CNB, PCUBC dan Hiley. Berdasarkan hasil perhitungan daya dukung dinamis didapat daya dukung terbesar yaitu menggunakan metode ENR-Modified pada tiang P1.2 dan P3.2 dengan $s=12 \mathrm{~mm}$ masing-masing sebesar 83,488 ton sedangkan daya dukung terkecil yaitu menggunakan metode PCUBC pada tiang P2.2. dengan s=24 mm sebesar 35,470 ton.
\end{abstract}

Kata kunci: pondasi tiang pancang, formula dinamis, pengujian calendering, daya dukung

\section{Pendahuluan}

Struyk[1] mengatakan bahwa jembatan merupakan sebuah konstruksi yang terdiri dari struktur atas dan struktur bawah yang berfungsi untuk menghubungkan dua ruas jalan yang terputus akibat adanya rintangan yang lebih rendah seperti sungai, jalan, irigasi, dan sebagainya.

Perencanaan pada jembatan perlu diberikan perhatian khusus terutama pada struktur bawahnya yaitu pondasi. Pondasi merupakan sebuah sistem rekayasa yang berfungsi untuk menahan dan meneruskan beban struktur atas serta beratnya sendiri ke lapisan tanah keras yang berada di bawahnya [2].

Permasalahan yang kerap terjadi pada pondasi biasanya berkaitan dengan properties tanah dan lemahnya daya dukung tanah yang mengakibatkan penurunan pondasi berlebihan dan tidak merata hingga menyebabkan keruntuhan.

Objek yang menjadi tinjauan dalam penelitian ini adalah Proyek Pelebaran Jembatan Alue Lamteh. Jembatan Alue Lamteh berada di Desa Keumireue, Kecamatan Kuta Cot Glie, Kabupaten Aceh Besar pada titik koordinat $5^{\circ} 23^{\prime} 42,4^{\prime \prime}$ LU dan $95^{\circ} 29^{\prime} 35,9^{\prime \prime}$ BT dan berada dekat dengan 2 lokasi sumber gempa di Provinsi Aceh, diantaranya Patahan Seulimum dan Gunung Vulkanik Seulawah.

Jembatan Alue Lamteh merupakan salah satu jembatan yang masuk ke dalam ruas Jalan Nasional Banda Aceh-Medan. Hal ini yang juga menyebabkan jembatan ini mengalami peningkatan volume lalu lintas sehingga perlu dilakukan pelebaran pada sisi kiri dan kanan badan jembatan.

Tujuan dari penelitian ini adalah untuk menganalisis daya dukung pondasi tiang pancang menggunakan formula dinamis pada jembatan Alue Lamteh. Daya dukung dinamis tiang pancang dihitung menggunakan metode Janbu, ENR-Modified, CNB, PCUBC dan Hiley.

\section{Tinjauan Kepustakaan}

Tinjauan kepustakaan berisi kerangka konseptual yang ditulis berdasarkan kaidah ilmiah dalam pemecahan masalah terdiri dari laporan penelitian, jurnal-jurnal ilmiah dan pendapat para ahli. Pada bagian ini mengemukakan kutipan mengenai analisis daya dukung dinamis tiang. 


\subsection{Tiang pancang}

Tiang pancang merupakan salah satu bagian konstruksi yang biasanya terbuat dari baja, kayu, maupun beton yang berfungsi untuk meneruskan beban dari struktur atas ke lapisan tanah keras yang dalam [2].

Pondasi tiang pancang biasanya digunakan untuk memberikan daya dukung pada bangunan jika tanah keras berada sangat dalam. Selain itu, fondasi juga berfungsi untuk menahan gaya angkat pada bangunan tingkat tinggi yang dipengaruhi oleh gaya guling akibat beban angin [3].

\subsection{Jenis-jenis pondasi tiang pancang}

Hardiyatmo[3] membagi tiang pancang berdasarkan bentuk dan jenis tiang pancang menjadi 3 kategori, diantaranya:

a. Large displacement pile atau disebut Tiang perpindahan besar.

b. Small displacement pile atau disebut tiang perpindahan kecil.

c. non-displacement pile atau disebut tiang tanpa perpindahan

Hardiyatmo[3] membagi pula tiang pancang berdasarkan material tiang pancang menjadi 6 kategori, diantaranya:
a. Tiang pancang kayu
b. Tiang beton pracetak
c. Tiang beton cetak di tempat
d. Tiang bor
e. Tiang baja profil
f. Tiang komposit

Tomlinson[4] juga menyatakan terdapat beberapa tiang pancang yang umumnya digunakan dalam konstruksi, antara lain:

a. Driven piles, yaitu tiang pancang yang telah dibentuk terlebih dahulu yang terbuat dari kayu, baja, atau beton lalu dipancang dengan hammer

b. Driven and cast in places pile, yaitu tiang pancang yang dicetak dilokasi pemancangan.

c. Screw piles, yaitu tiang pancang baja yang diputar masuk ke dalam lapisan tanah.

d. Bore piles, yaitu tiang pancang beton yang terbuat dari pengecoran beton ke dalam lubang yang telah dibuat.

e. Vibration piles driven, menurut Holeyman [5], yaitu tiang pancang yang dimasukkan ke dalam tanah dengan cara digetarkan.

f. Hydraulic pile driven, yaitu tiang pancang yang menggunakan mesin penekan (Jack Hydraulic) agar tiang dapat masuk ke dalam tanah.

g. Kneading, yaitu metode pembentukan pondasi padat pada tanah lunak yang dicampur dengan bahan kimia sebagai bahan perkuatan tanah.

\subsection{Metode Pemancangan Tiang Pancang}

Proses pemancangan tiang pancang ke dalam tanah dapat menggunakan diesel hammer, vibratory hammer ataupun drop hammer. Menurut Hardiyatmo [3], metode pemancangan tiang berdasarkan penggunaan jenis pemukul (hammer), terbagi atas:

a. Tiang pancang dengan menggunakan pemukul jatuh (drop hammer)

a. Tiang pancang dengan menggunakan pemukul aksi tunggal (single acting hammer)

b. Tiang pancang dengan menggunakan pemukul aksi double (double acting hammer)

c. Tiang pancang dengan menggunakan pemukul diesel (diesel hammer)

d. Tiang pancang dengan menggunakan pemukul getar (vibratory hammer)

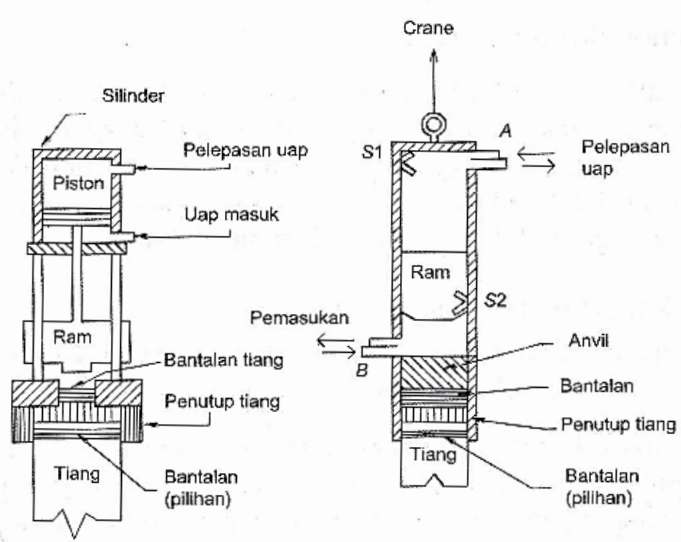

(a)

(b)

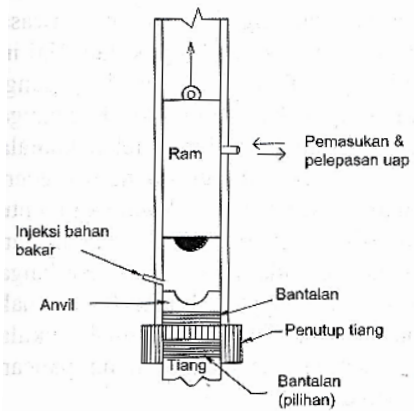

(c)

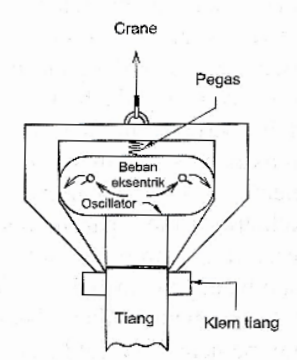

(d)
Gambar 1 Skema pemukul tiang: (a) pemukul aksi tunggal; (b) pemukul aksi ganda; (c) pemukul diesel; (d) pemukul getar. Sumber: Hardiyatmo (2018)

\subsection{Teori Daya Dukung Tiang Pancang Menggunakan Metode Dinamis}

Tobing[6] Metode dinamis merupakan salah satu pengujian tiang pancang menggunakan data calendering berdasarkan analisis data rekaman getaran yang terjadi ketika tiang pancang dipancang menggunakan alat pancang. 
Mulyono[7] menyatakan bahwa kapasitas daya dukung yang harus dicapai oleh sebuah tiang pancang harus dapat menopang beban aksial yang bekerja di atasnya. Oleh karena itu dibutuhkan sebuah cara di lapangan untuk mengontrol tercapainya nilai daya dukung sebuah tiang pancang yang ingin didapatkan melalui nilai penetrasi perpukulan yang diperoleh dari data pemancangan di lapangan.

\subsection{Pengujian calendering}

Lilian [8] menyatakan pengujian calendering umumnya dillaksanakan saat proses pemancangan tiang pancang beton maupun baja untuk mengetahui daya dukung dinamisnya. Ketika kedalaman yang direncanakan sudah tercapai, maka akan dilakukan pengujian calendering untuk mendapatkan nilai final set (s) tiang pancang persepuluh pukulan terakhir untuk dijadikan acuan dalam perhitungan daya dukung menggunakan formula dinamis. Pengujian calendering ini menggunakan kertas milimeter yang ditempel pada tiang pancang, alat tulis atau pensil, waterpass dan penyangga kayu.

Rahmita [9] juga mengatakan bahwa semakin kecil nilai final set (s) maka daya dukung yang didapatkan akan semakin besar, dan sebaliknya semakin besar nilai final set (s) maka nilai daya dukung tanah semakin kecil.

\subsection{Perhitungan daya dukung dengan metode formula dinamis}

Bowles[1] menyatakan terdapat 10 metode formula dinamis yang dapat digunakan dalam menghitung nilai daya dukung dinamis sebuah tiang pancang, antara lain:

\subsubsection{Metode Janbu}

Bowles[2] menjelaskan dalam menghitung daya dukung tiang pancang menggunakan hasil pengujian calendering, dapat dihitung dengan memakai metode Janbu, menggunakan Persamaan (2-1). Metode ini dapat digunakan dengan nilai Safety Factor (SF) sebesar 3 sampai 6:

$$
Q u=\frac{e_{h} \cdot E_{h}}{k_{u} \cdot s}
$$

Keterangan: $\mathrm{Qu}=$ kapasitas daya dukung tiang pancang ultimit (ton); eh = efisiensi pemukul; Eh= besaran energi pemukul; s = besarnya penetrasi per pukulan $(\mathrm{mm}) ; \mathrm{Ku}=$ kompresi tiang pancang.

Nilai eh seperti diperlihatkan dalam Tabel 1, yakni nilai efisiensi alat menurut jenis alat yang dipakai.

Tabel 1 Nilai efisiensi alat

\begin{tabular}{cc}
\hline Jenis alat & $\begin{array}{c}\text { Efisiensi alat } \\
(\mathbf{e h})\end{array}$ \\
\hline Single acting & $0,75-1,00$ \\
\hline
\end{tabular}

\begin{tabular}{cc}
\hline Double acting & 0,85 \\
\hline Diesel hammer & $0,85-1,00$ \\
\hline Drop hammer & $0,75-1,00$ \\
\hline
\end{tabular}

Sumber: Mulyono (2015)

\subsubsection{Metode ENR-Modified}

Bowles[2] menjelaskan dalam menghitung daya dukung tiang pancang menggunakan hasil pengujian calendering, dapat dihitung dengan memakai metode ENR-Modified, menggunakan Persamaan (2-2). Metode ini dapat digunakan dengan nilai Safety Factor (SF) sebesar 6:

$$
Q u=\frac{1,25 \cdot e_{h} \cdot E_{h}}{s+0,1} \frac{W_{r}+n^{2} W_{p}}{W_{r}+W_{p}}
$$

Keterangan: $\mathrm{Qu}=$ kapasitas daya dukung tiang pancang ultimit (ton); eh = efisiensi pemukul; Eh = besaran energi pemukul; $\mathrm{s}=$ besarnya penetrasi per pukulan $(\mathrm{mm}) ; \mathrm{n}=$ koefisien restitusi; $\mathrm{Wr}=$ berat pemukul (ton); $\mathrm{Wp}=$ berat tiang pancang (ton)

Nilai $e_{h}$ seperti diperlihatkan dalam Tabel 1, yakni nilai efisiensi alat menurut jenis alat yang dipakai.

\subsubsection{Metode Canadian National Building (CNB)}

Bowles[2] menjelaskan dalam menghitung daya dukung tiang pancang menggunakan hasil pengujian calendering, dapat dihitung dengan memakai metode CNB, menggunakan Persamaan (2-3). Metode ini dapat digunakan dengan nilai Safety Factor (SF) sebesar 6:

$$
Q u=\frac{e_{h} E_{h} C_{1}}{s+C_{2} C_{3}}
$$

Keterangan: $\mathrm{Qu}=$ kapasitas daya dukung tiang pancang ultimit (ton); eh = efisiensi pemukul; Eh $=$ besaran energi pemukul; $\mathrm{n}=$ koefisien restitusi; $\mathrm{C} 1=$ koefisien perbandingan berat pemukul dan berat tiang; $\mathrm{C} 2$ = koefisien perbandingan daya dukung dengan luas tiang; C3 = koefisien perbandingan panjang dengan elastisitas tiang; $\mathrm{s}=$ besarnya penetrasi per pukulan $(\mathrm{mm}) ; \mathrm{Wr}=$ berat pemukul (ton); $\mathrm{Wp}=$ berat tiang pancang (ton).

Nilai $e_{h}$ seperti diperlihatkan dalam Tabel 1, yakni nilai efisiensi alat menurut jenis alat yang dipakai.

\subsubsection{Metode Pacific Coast Uniform Building Code (PCUBC)}

Bowles[2] menjelaskan dalam menghitung daya dukung tiang pancang menggunakan hasil pengujian calendering, dapat dihitung dengan memakai metode PCUBC, menggunakan Persamaan (2-4). Metode ini 
dapat digunakan dengan nilai Safety Factor (SF) sebesar 4:

$$
Q u=\frac{e_{h} E_{h} C_{1}}{s+C_{2}}
$$

Keterangan: $\mathrm{Qu}=$ kapasitas daya dukung tiang pancang ultimit (ton); eh = efisiensi pemukul; $\mathrm{Eh}=$ besaran energi pemukul; $\mathrm{s}=$ besarnya penetrasi per pukulan $(\mathrm{mm}) ; \mathrm{C} 1=$ koefisien perbandingan berat pemukul dan berat tiang; $\mathrm{C} 2=$ koefisien perbandingan daya dukung dengan luas tiang;

Nilai $e_{h}$ seperti diperlihatkan dalam Tabel 1, yakni nilai efisiensi alat menurut jenis alat yang dipakai.

\subsubsection{Metode Hiley}

Bowles[2] menjelaskan dalam menghitung daya dukung tiang pancang menggunakan hasil pengujian calendering, dapat dihitung dengan memakai metode Hiley, menggunakan Persamaan (25). Metode ini dapat digunakan dengan nilai Safety Factor (SF) sebesar 4:

$$
Q u=\frac{e_{h} E_{h}}{s+\frac{1}{2}\left(k_{1}+k_{2}+k_{3}\right)} \frac{W_{r}+n^{2} W_{p}}{W_{r}+W_{p}}
$$

Keterangan: $\mathrm{Qu}=$ kapasitas daya dukung tiang pancang ultimit (ton); eh = efisiensi pemukul; Eh = besaran energi pemukul; $\mathrm{n}=$ koefisien restitusi; $\mathrm{k} 1$ = kompresi elastis capblock dan pile cap; $\mathrm{k} 2$ = kompresi elastis tiang; k3 = kompresi elastis tanah; s = besarnya penetrasi per pukulan $(\mathrm{mm}) ; \mathrm{Wr}=$ berat pemukul (ton); $\mathrm{Wp}=$ berat tiang pancang (ton).

Nilai $e_{h}$ seperti diperlihatkan dalam Tabel 1, yakni nilai efisiensi alat menurut jenis alat yang dipakai.

\section{Metodologi Penelitian}

Metodologi penelitan berisi mengenai prosedur yang digunakan dalam penelitian yang dimulai dari pengumpulan data dan perhitungan kapasitas daya dukung tiang pancang menggunakan formula dinamis.

\subsection{Pengumpulan data sekunder}

Data sekunder adalah data yang diperoleh dari sumber yang sudah ada. Dalam perhitungan menggunakan formula dinamis ini diperlukan datadata pendukung, yang berhubungan dengan pelaksanaan pemancangan di lapangan.

Berikut ini adalah data sekunder yang digunakan dalam penelitian ini, antara lain:

a. Detail Engineering Design (DED) Proyek Pelebaran Jembatan Alue Lamteh b. Nilai final set (s) pengujian calendering

- $\mathrm{P} 1.2=12 \mathrm{~mm}$

- $\quad \mathrm{P} 2.2=24 \mathrm{~mm}$

- $\quad \mathrm{P} 3.2=12 \mathrm{~mm}$

- $\mathrm{P} 4.2=17 \mathrm{~mm}$

c. Berat hammer $=3,5$ ton

d. Tinggi jatuh hammer $=2,5$ meter

e. Berat tiang pancang $=5,13$ ton

f. Panjang tiang pancang $=17$ meter

g. Diameter tiang pancang $=50 \mathrm{~cm}$

h. Kuat tekan tiang pancang $\left(\mathrm{fc}^{\prime}\right)=30 \mathrm{MPa}$.

\subsection{Metode perhitungan daya dukung dinamis}

Perhitungan daya dukung tiang pancang menggunakan formula dinamis didapatkan dari hasil nilai final set (s). Persamaan yang digunakan dalam penelitian ini berdasarkan Bowles[2], yaitu Janbu, ENR-Modified, CNB, PCUBC, dan Hiley.

Tobing[6] Hasil perhitungan kapasitas daya dukung menggunakan formula dinamis ini akan dibagi dengan safety factor (SF) sesuai dengan metode yang digunakan sehingga akan menghasilkan nilai daya dukung dengan pertimbangan dan faktor aman yang baik.

\section{Hasil dan Pembahasan}

Bagian ini merupakan hasil dan pembahasan penelitian berdasarkan pengolahan data primer dan data sekunder yaitu berupa hasil perhitungan nilai daya dukung tiang pancang menggunakan formula dinamis pada proyek pelebaran Jembatan Alue Lamteh.

\subsection{Nilai daya dukung dinamis metode Janbu}

Berdasarkan hasil perhitungan menggunakan persamaan 2-1, didapatkan nilai daya dukung terendah pada metode Janbu dengan nilai final set (s) $24 \mathrm{~mm}$ yaitu pada tiang P2.2 sebesar Qall $=37,963$ ton, sedangkan nilai daya dukung tertinggi dengan nilai final set (s) $12 \mathrm{~mm}$ yaitu pada tiang P1.2 dan P3.2 masing masing sebesar Qall $=65,325$ ton. Rekapitulasi nilai daya dukung dinamis metode Janbu seperti diperlihatkan dalam Tabel 1.

Tabel 1 Rekapitulasi nilai daya dukung dinamis metode Janbu

\begin{tabular}{ccc}
\hline No. Tiang & s (mm) & Qall (ton) \\
\hline P1.2 & 12,0 & 65,325 \\
\hline P2.2 & 24,0 & 37,963 \\
\hline P3.2 & 12,0 & 65,325 \\
\hline P4.2 & 17,0 & 50,546 \\
\hline
\end{tabular}

Grafik hubungan antara nilai final set (s) dengan daya dukung tiang pancang metode Janbu seperti diperlihatkan dalam Gambar 2 menunjukkan bahwa semakin besar nilai final set (s) maka akan semakin kecil nilai daya dukung yang akan dihasilkan oleh sebuah tiang pancang dan sebaliknya semakin kecil 
nilai final set (s) maka akan semakin besar pula daya dukung tiang pancang.

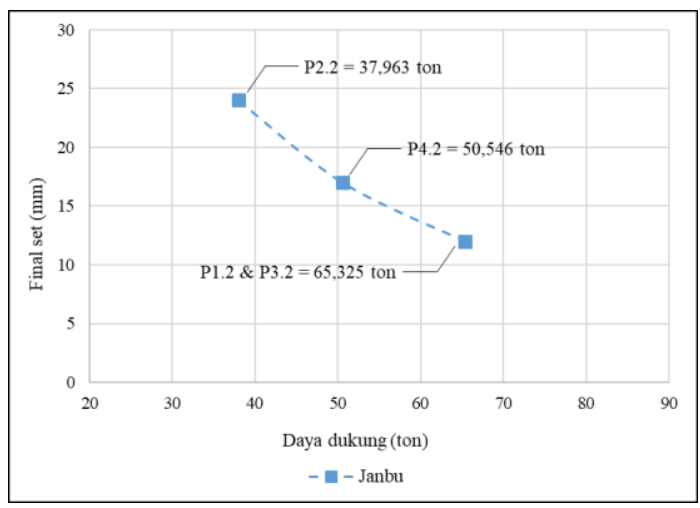

Gambar 2 Grafik hubungan antara nilai final set (s) dengan daya dukung tiang pancang metode Janbu

\subsubsection{Nilai daya dukung dinamis metode ENR- Modified}

Berdasarkan hasil perhitungan menggunakan persamaan 2-2, didapatkan nilai daya dukung terendah pada metode ENR-Modified dengan nilai final set (s) $24 \mathrm{~mm}$ yaitu pada tiang P2.2 sebesar Qall $=41,917$ ton, sedangkan nilai daya dukung tertinggi dengan nilai final set (s) $12 \mathrm{~mm}$ yaitu pada tiang P1.2 dan P3.2 masing masing sebesar Qall $=83,488$ ton. Rekapitulasi nilai daya dukung dinamis metode ENRModified seperti diperlihatkan dalam Tabel 2.

Tabel 2 Rekapitulasi nilai daya dukung dinamis metode ENR-Modified

\begin{tabular}{ccc}
\hline No. Tiang & s (mm) & Qall (Ton) \\
\hline P1.2 & 12,0 & 83,488 \\
\hline P2.2 & 24,0 & 41,917 \\
\hline P3.2 & 12,0 & 83,488 \\
\hline P4.2 & 17,0 & 59,077 \\
\hline
\end{tabular}

Grafik hubungan antara nilai final set (s) dengan daya dukung tiang pancang metode ENR-Modified seperti diperlihatkan dalam Gambar 3 menunjukkan bahwa semakin besar nilai final set (s) maka akan semakin kecil nilai daya dukung yang akan dihasilkan oleh sebuah tiang pancang dan sebaliknya semakin kecil nilai final set (s) maka akan semakin besar pula daya dukung tiang pancang.

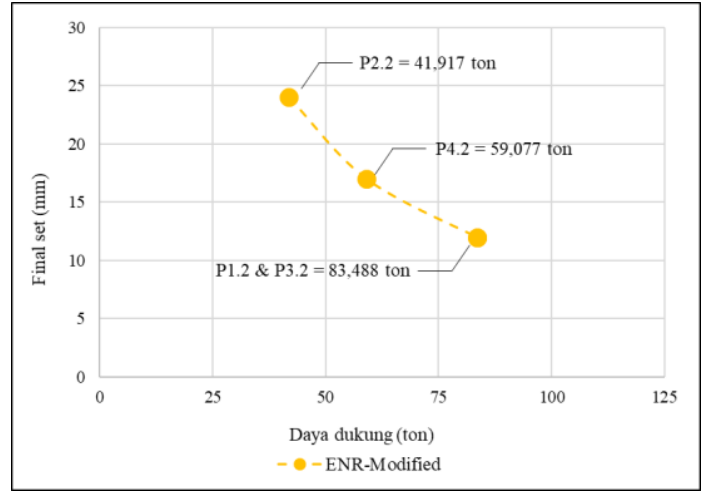

Gambar 3 Grafik hubungan antara nilai final set (s) dengan daya dukung tiang pancang metode Janbu

\subsubsection{Nilai daya dukung dinamis metode CNB}

Berdasarkan hasil perhitungan menggunakan persamaan 2-3, didapatkan nilai daya dukung terendah pada metode CNB dengan nilai final set (s) $24 \mathrm{~mm}$ yaitu pada tiang P2.2 sebesar Qall $=45,508$ ton, sedangkan nilai daya dukung tertinggi dengan nilai final set (s) $12 \mathrm{~mm}$ yaitu pada tiang P1.2 dan P3.2 masing masing sebesar Qall $=64,759$ ton. Rekapitulasi nilai daya dukung dinamis metode CNB seperti diperlihatkan dalam Tabel 3.

Tabel 3 Rekapitulasi nilai daya dukung dinamis metode CNB

\begin{tabular}{ccc}
\hline No. Tiang & s (mm) & Qall (Ton) \\
\hline P1.2 & 12,0 & 64,759 \\
\hline P2.2 & 24,0 & 45,508 \\
\hline P3.2 & 12,0 & 64,759 \\
\hline P4.2 & 17,0 & 55,467 \\
\hline
\end{tabular}

Grafik hubungan antara nilai final set (s) dengan daya dukung tiang pancang metode CNB seperti diperlihatkan dalam Gambar 4 menunjukkan bahwa semakin besar nilai final set (s) maka akan semakin kecil nilai daya dukung yang akan dihasilkan oleh sebuah tiang pancang dan sebaliknya semakin kecil nilai final set (s) maka akan semakin besar pula daya dukung tiang pancang.

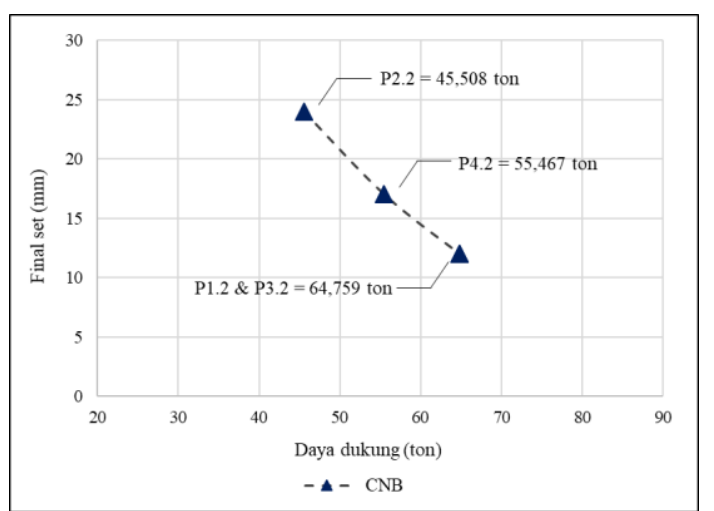

Gambar 4 Grafik hubungan antara nilai final set (s) dengan daya dukung tiang pancang metode CNB 
4.1.4 Nilai daya dukung dinamis metode PCUBC

Berdasarkan hasil perhitungan menggunakan persamaan 2-4, didapatkan nilai daya dukung terendah pada metode PCUBC dengan nilai final set (s) $24 \mathrm{~mm}$ yaitu pada tiang P2.2 sebesar Qall $=35,470$ ton, sedangkan nilai daya dukung tertinggi dengan nilai final set (s) $12 \mathrm{~mm}$ yaitu pada tiang P1.2 dan P3.2 masing masing sebesar Qall $=53,414$ ton. Rekapitulasi nilai daya dukung dinamis metode PCUBC seperti diperlihatkan dalam Tabel 4.

Tabel 4 Rekapitulasi nilai daya dukung dinamis metode PCUBC

\begin{tabular}{ccc}
\hline No. Tiang & s (mm) & Qall (Ton) \\
\hline P1.2 & 12,0 & 53,414 \\
\hline P2.2 & 24,0 & 35,470 \\
\hline P3.2 & 12,0 & 53,414 \\
\hline P4.2 & 17,0 & 44,485 \\
\hline
\end{tabular}

Grafik hubungan antara nilai final set (s) dengan daya dukung tiang pancang metode PCUBC seperti diperlihatkan dalam Gambar 5 menunjukkan bahwa semakin besar nilai final set (s) maka akan semakin kecil nilai daya dukung yang akan dihasilkan oleh sebuah tiang pancang dan sebaliknya semakin kecil nilai final set (s) maka akan semakin besar pula daya dukung tiang pancang.

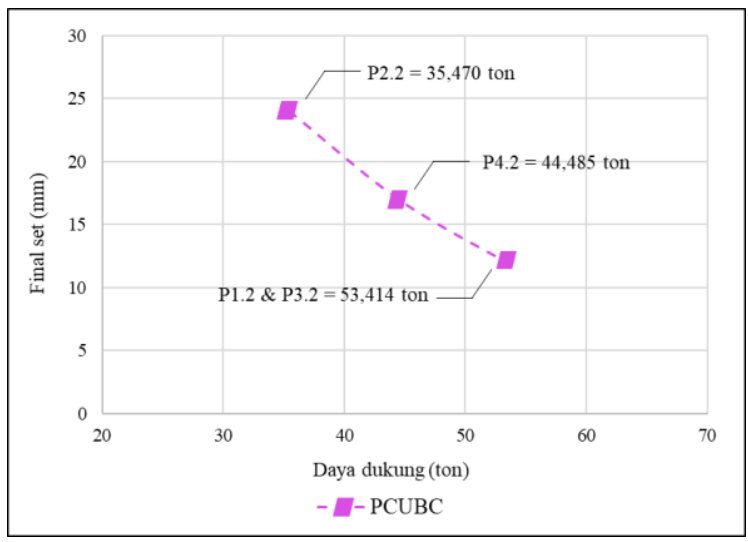

Gambar 5 Grafik hubungan antara nilai final set (s) dengan daya dukung tiang pancang metode PCUBC

\subsubsection{Nilai daya dukung dinamis metode Hiley}

Berdasarkan hasil perhitungan menggunakan persamaan 2-5, didapatkan nilai daya dukung terendah pada metode Hiley dengan nilai final set (s) $24 \mathrm{~mm}$ yaitu pada tiang P2.2 sebesar Qall $=35,470$ ton, sedangkan nilai daya dukung tertinggi dengan nilai final set (s) $12 \mathrm{~mm}$ yaitu pada tiang P1.2 dan P3.2 masing masing sebesar Qall = 53,414 ton. Rekapitulasi nilai daya dukung dinamis metode Hiley seperti diperlihatkan dalam Tabel 5.
Tabel 5 Rekapitulasi nilai daya dukung dinamis metode Hiley

\begin{tabular}{ccc}
\hline No. Tiang & s (mm) & Qall (Ton) \\
\hline P1.2 & 12,0 & 63,911 \\
\hline P2.2 & 24,0 & 41,142 \\
\hline P3.2 & 12,0 & 63,911 \\
\hline P4.2 & 17,0 & 52,255 \\
\hline
\end{tabular}

Grafik hubungan antara nilai final set (s) dengan daya dukung tiang pancang metode Hiley seperti diperlihatkan dalam Gambar 6 menunjukkan bahwa semakin besar nilai final set (s) maka akan semakin kecil nilai daya dukung yang akan dihasilkan oleh sebuah tiang pancang dan sebaliknya semakin kecil nilai final set (s) maka akan semakin besar pula daya dukung tiang pancang.

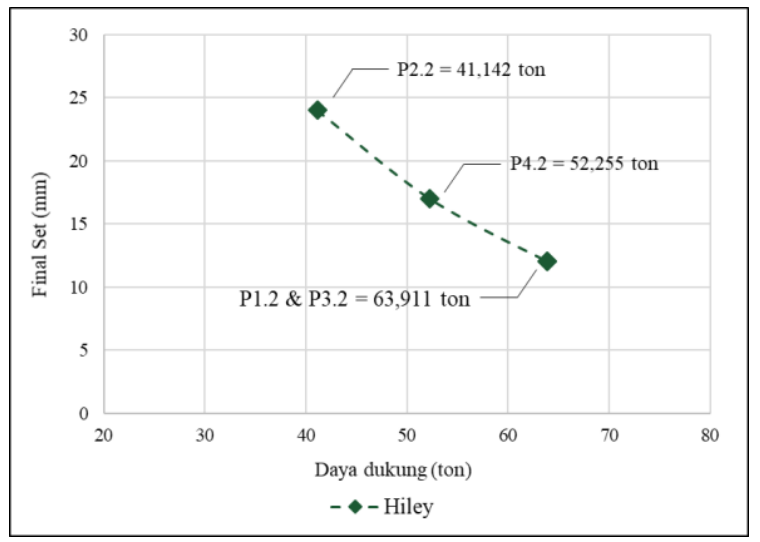

Gambar 6 Grafik hubungan antara nilai final set (s) dengan daya dukung tiang pancang metode Hiley

\subsubsection{Hubungan antara nilai daya dukung dinamis dengan nilai final set (s)}

Seperti diperlihatkan dalam Gambar 7 yaitu grafik gabungan hubungan antara nilai final set (s) dengan daya dukung tiang pancang menggunakan formula dinamis menggunakan metode Janbu, metode ENR-Modified, metode Canadian National Building (CNB), metode Pacific Coast Uniform Building Code (PCUBC), dan metode Hiley. Dapat diamati bahwa metode ENR-Modified menunjukkan nilai daya dukung tiang pancang terbesar sedangkan metode PCUBC menunjukkan nilai daya dukung tiang pancang terkecil. 


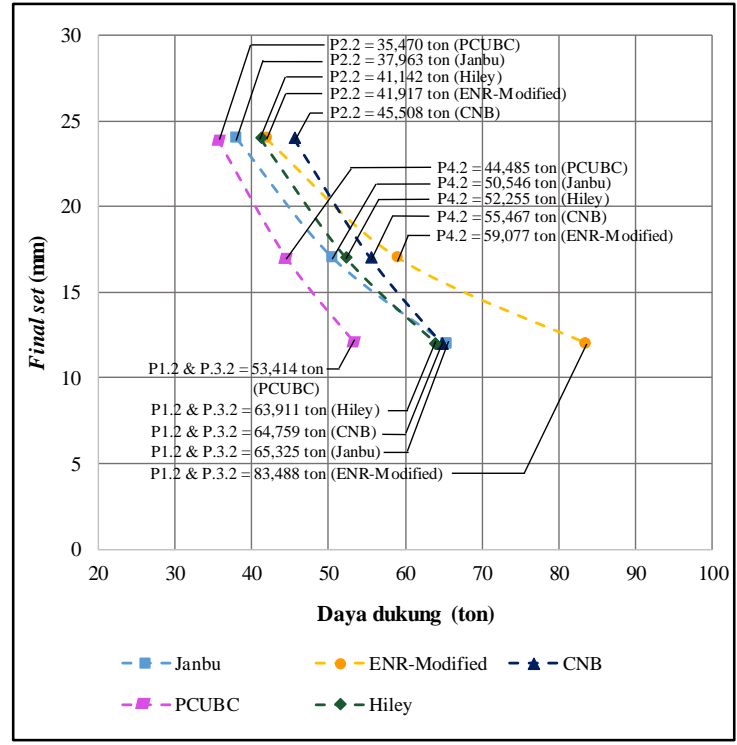

Gambar 7 Grafik gabungan hubungan antara nilai final set (s) dengan daya dukung tiang pancang menggunakan formula dinamis

Berdasarkan grafik hubungan antara nilai final set (s) dengan daya dukung tiang pancang menggunakan formula dinamis, dapat disimpulkan bahwa semakin kecil nilai final set (s) hasil pengujian calendering ini, maka nilai daya dukung yang dihasilkan dalam perhitungan formula dinamis ini semakin besar dan sebaliknya apabila semakin besar nilai final set (s) maka nilai daya dukung yang akan dihasilkan juga semakin kecil.

\section{Kesimpulan dan saran}

Berdasarkan hasil perhitungan dan analisis daya dukung dengan formula dinamis didapat beberapa kesimpulan, yaitu nilai daya dukung dinamis terbesar yaitu menggunakan metode ENR-Modified pada tiang P1.2 dan P3.2 dengan $\mathrm{s}=12 \mathrm{~mm}$ masing-masing sebesar 83,488 ton sedangkan Qu terkecil yaitu menggunakan metode PCUBC pada tiang P2.2 dengan $\mathrm{s}=24 \mathrm{~mm}$ sebesar 35,470 ton. Semakin besar nilai final set (s) maka nilai daya dukung yang akan dihasilkan juga semakin kecil sedangkan jika semakin kecil nilai final set (s) maka nilai daya dukung yang dihasilkan dalam akan semakin besar.

Adapun saran yang dapat diberikan yaitu untuk mendapatkan nilai kapasitas daya dukung yang lebih akurat dapat dihitung menggunakan beberapa metode formula dinamis lainnya yaitu seperti metode AASHTO, Navy-McKay, Gates, Danish dan Eytelwein.

\section{Daftar pustaka}

[1] Struyk, H.J. dan Veen, K.H.C.W. 1984. Jembatan. Jakarta: PT. Pradnya Paramita.

[2] Bowles, J.E. 1997. Analisa dan Desain Pondasi Jilid 1. Jakarta: Penerbit Erlangga.

[3] Hardiyatmo, H.C. 2018. Analisis dan Perancangan Fondasi II. Yogyakarta: Gadjah
Mada University Press.

Tomlinson, M., Woodward, J. 1994. Pile Design and Construction Practice. London and Newyork: Francis and Taylor Group.

Holeyman, A. 2000. Vibratory Pile Driving. Belgia: UCLouvain.

B. M. L. Tobing, "Perbandingan Kapasitas Penggunaan Formula Dinamis Pada Tiang Pancang Sebagai Kontrol Daya Dukung," J. Civ. Eng. Student, vol. 1, no. 3, pp. 43-49, 2019, [Online]. Available: http://www.jim.unsyiah.ac.id/CES/article/vie w/8244.

Mulyono, T. 2015. Teknik Pondasi 2 Pondasi Dalam. Jakarta: Universitas Negeri Jakarta.

Lilian, F., Munirwansyah, Yunita, H. 2020. Kontrol Kapasitas Daya Dukung Pondasi Tiang Pancang dengan Metode Formula Dinamis dan Analisis Pacific Coast Uniform Building Code (Studi Kasus Pondasi Wisma District Sales Office (DSO) Djarum, Kota Banda Aceh. Tugas Akhir: Universitas Syiah Kuala.

[9] Rahmita, A.K., Munirwansyah, Khaizal. 2020. Tinjauan Daya Dukung Pondasi Tiang Pancang (Precast Concrete Mini Pile) dengan Metode Formula Dinamis dan Analisis Navy-Mckay (Studi Kasus Pondasi Gedung District Sales Office (DSO) Djarum, Kota Banda Aceh). Tugas Akhir: Universitas Syiah Kuala. 